\title{
On some ecological aspects of the lugworm Abarenicola affinis chiliensis Wells, 1963 (Polychaeta: Scolecida: Arenicolidae) from shallow soft bottoms of northern Chile
}

\author{
Rodrigo A. Moreno $\cdot$ Nicolás Rozbaczylo $\cdot$ Roger D. Sepúlveda $\cdot$ \\ Milko I. Marinkovic $\cdot$ Wolf E. Arntz $\cdot$ Sven Thatje
}

Received: 22 November 2005/Revised: 24 July 2006/ Accepted: 26 July 2006/Published online: 6 September 2006

(C) Springer-Verlag and AWI 2006

\begin{abstract}
We conducted an ecological study of a population of the polychaete Abarenicola affinis chiliensis in the shallow subtidal zone of Caleta Guardiamarina Riquelme in northern Chile. The study area is characterized by a hypoxic bottom consisting of fine sands and a silt-clay mixture, with high values of total organic matter content (TOM $>20 \%$ ). During the two study periods (spring 1996 and 1997), the numerical contribution of $A$. affinis chiliensis to the total macrofauna was greater than $80 \%$. A similar pattern was recorded for biomass, with A. affinis chiliensis surpassing $95 \%$ of the total macrofauna biomass. Statistical analyses did not detect significant differences in
\end{abstract}

Communicated by H.-D. Franke

R. A. Moreno $(\bowtie) \cdot N$. Rozbaczylo

Departamento de Ecología,

Facultad de Ciencias Biológicas,

Pontificia Universidad Católica de Chile,

Casilla 114-D, Santiago 6513667, Chile

e-mail: romoren@bio.puc.cl

R. D. Sepúlveda

Instituto de Ecología y Evolución, Facultad de Ciencias,

Universidad Austral de Chile, Casilla 567, Valdivia, Chile

\section{I. Marinkovic}

Departamento de Ciencias del Mar,

Universidad Arturo Prat, Casilla 121, Iquique, Chile

W. E. Arntz

Alfred Wegener Institute for Polar and Marine Research,

Columbusstrasse, 27568 Bremerhaven, Germany

S. Thatje

National Oceanography Centre,

University of Southampton, European Way,

Southampton SO14 3ZH, UK environmental and biotic variables between years (with the exception of salinity, which increased slightly), indicating temporal stability of these variables over the study period. Our results do not support the hypothesis of Wells that seawater temperatures act as a physical barrier impeding the dispersal of Abarenicola species. This hypothesis should be reexamined for some representatives of Abarenicola on the Pacific coast of South America.

Keywords Abarenicola affinis chiliensis $\cdot$ Peruvian Province $\cdot$ Warm temperate waters $\cdot$ Southeastern Pacific $\cdot$ Chile

\section{Introduction}

Arenicolidae Johnston ("lugworms") is a small taxon with 30 nominal species (Rouse and Pleijel 2001) separated into four genera, which are distributed around the world (Wells 1964; Hutchings 2000): Abarenicola Wells, Arenicola Lamarck, Arenicolides Mesnil and Branchiomaldane Langerhans (Wells 1959). The species of this family form a monophyletic group characterized by the presence of glandular caeca (Fauchald and Rouse 1997). Some species of this group have direct economic importance given the use of lugworms as bait for sport and recreational fishing (e.g., Arenicola marina) on European and American coasts (McLusky et al. 1983; see review in Hutchings 2000; Rouse and Pleijel 2001). Recent studies on Arenicola marina have shown that its hemoglobin may be a promising blood substitute in human medicine (Zal et al. 2002). 
Lugworms (Arenicola and Abarenicola spp.) occur in dense populations in soft sediments in intertidal and shallow subtidal zones throughout the world (Wells 1963b; Hobson 1967; Jacobsen 1967; Hutchings 2000). Some species of lugworms (e.g. A. marina) dominate faunal communities, in terms of abundance and biomass, on muddy sand flats (Jacobsen 1967; Flach and Beukema 1994). Lugworms have been catalogued as particle-feeders (Hutchings 2000) and also perform important functions by reworking the sediment and redistributing labile organic matter downward within the seabed (e.g., Abarenicola) (see Swinbanks 1981; Levin et al. 1997).

Global zoogeographic studies of the genera Arenicola and Abarenicola (Wells 1963b, 1964) have allowed for the classification of the species' distributions into three large zones: a northern cold-water zone, a central warm-water zone and a southern cold-water zone. The limits separating these three zones correspond mainly to the summer surface-water isotherm at $20^{\circ} \mathrm{C}$, and the southern cold-water isotherm at $10^{\circ} \mathrm{C}$. Wells (1963b, 1964) indicate that the genus Arenicola probably radiated out from an ancestral stock in the northern cold water zone, while Abarenicola came from an ancestral form in the southern cold water zone. Temperature barriers were likely the most important factor permitting evolutionary differentiation of the species, by impeding dispersal, resulting in endemic clusters of forms in each zone.

On the southeastern Pacific coast of Chile only the genus Abarenicola has been registered, being represented by four species: Abarenicola pusilla (Quatrefages), which is distributed in warm temperate waters ( 29 and $41^{\circ}$ S) in the biogeographic Peruvian Province, and three species inhabiting cold temperate waters, $A$. affinis chiliensis Wells $\left(42^{\circ} \mathrm{S}\right)$, A. assimilis assimilis (Ehlers) and $A$. assimilis brevior $\left(53^{\circ} \mathrm{S}-55^{\circ} \mathrm{S}\right)$ (Wells 1954, 1963a), which inhabit the Magellanic Province (see Hernández et al. 2005; Moreno et al. 2006). However, currently there is no published information on the biology and ecology of these species that would permit comparative studies along the Chilean coast nor an evaluation of the hypothesis proposed by Wells (1963b, 1964) regarding temperature as a barrier that impedes the dispersal of Abarenicola in southeastern Pacific waters.

We conducted quantitative benthic surveys in warm temperate waters on the continental shelf of northern Chile, recording the presence of a population of A. affinis chiliensis (Fig. 1) in Iquique Bay $\left(20^{\circ} 10^{\prime} \mathrm{S}\right)$. Here we present the first data on the natural history of this species in the southeastern Pacific, and relate this information to some environmental variables

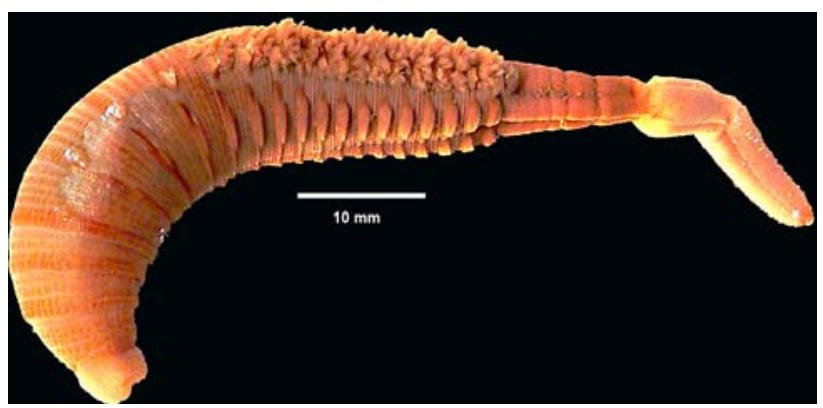

Fig. 1 Lateral view of a complete specimen of Abarenicola affinis chiliensis extracted from shallow soft bottom sediments of Caleta Guardiamarina Riquelme (CGR), in northern Chile

measured off the northern Chilean coast. Our objective is to utilize this new information to evaluate the hypothesis proposed by Wells (1963b).

\section{Materials and methods}

Study area

Iquique Bay is located in the northern zone of Chile $\left(20^{\circ} 10^{\prime} \mathrm{S}, 70^{\circ} 09^{\prime} \mathrm{W}\right)$ (Fig. 2). This bay covers an area of approximately $3 \mathrm{~km}^{2}$ and has an average depth of $35 \mathrm{~m}$. The study area is located at the southwestern end of the bay in Caleta Guardiamarina Riquelme (CGR), a protected area which covers about $6 \%$ of the total area of the bay and has an average depth of $3 \mathrm{~m}$, becoming progressively deeper towards the mouth of the bay. This area is characterized by the presence of a harbor with small and large scale fishing activities, a

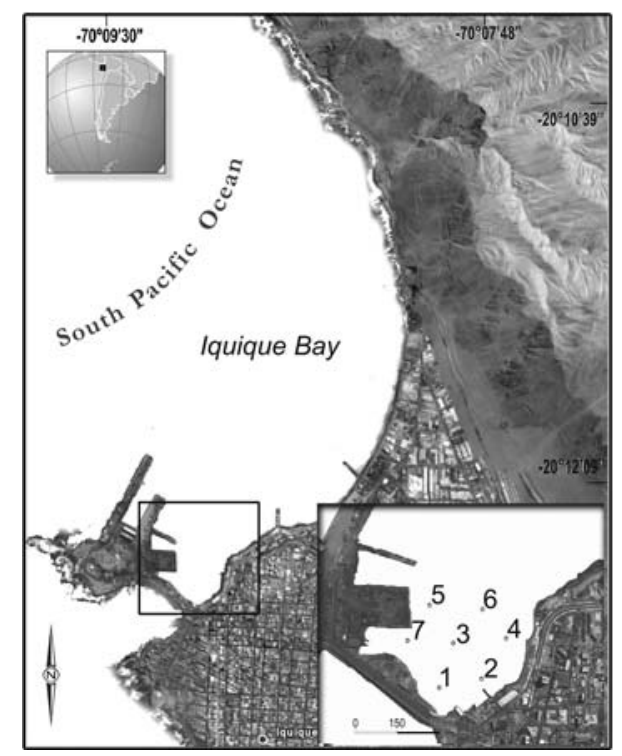

Fig. 2 Map indicating the position of the benthic sampling stations in CGR, Iquique Bay, northern Chile 
ship yard and a recreational sector. It receives sewage waste from domestic effluents and waste water from industrial fishing and shipping activities. The sector of CGR is semi-enclosed, with little circulation and low wave action. This area is characterized by the predominance of weak winds with long calm periods; an anti-clockwise circulation pattern in the central part of the bay generates a gyre, with waters flowing towards the north and northeast as a consequence of the bathymetry (Alvial and Moraga 1986). Water circulation in CGR is principally due to daily mixed tides with weak interior currents, which reduces water exchange and mixing. The sediment structure of CGR has been classified principally as fine sand and silt-clay (Marinkovic 2000).

\section{Sampling design}

The samples used in this study were obtained as part of a project to study the biodiversity of benthic macrofauna $(>0.5 \mathrm{~mm})$ on soft bottoms in northern Chile. Sampling was conducted during two benthic cruises aboard the R/V ANTARES of the Universidad Arturo Prat, during the spring of 1996 and 1997. We sampled seven benthic stations, with an average depth of $2 \mathrm{~m}$ (Fig. 2). At each station, we obtained three replicate sediment samples $\left(0.1 \mathrm{~m}^{2}\right)$ using a Van Veen grab. Two of the replicates were filtered using a geological sieve with $0.5 \mathrm{~mm}$ mesh size. The biological material obtained from these samples was fixed in $10 \%$ formalin. The third replicate was utilized for sediment and total organic matter (TOM) analyses. Together with the sediment samples we obtained water samples from $0.5 \mathrm{~m}$ above the bottom using Niskin bottles. These water samples were used to determine salinity (psu) and dissolved oxygen (DO) content $\left(\mathrm{ml} \mathrm{O}_{2} / \mathrm{l}\right)$.

\section{Data analysis}

Sediment data were obtained following the procedure described by Folk (1974). For particles less than $63 \mu \mathrm{m}$ the pipette method was used. Total organic matter was calculated as the percentage of weight lost by calcination at $550^{\circ} \mathrm{C}$ for two hours (Buchanan 1971). To determine salinity (S), we utilized an induction salinometer (TSK model E-2). Dissolved oxygen above the bottom was measured following the modified Winkler titration method (Strickland and Parsons 1972).

An inverse principal components analysis (PCA) was carried out to show the spatial distribution of variables (Jongman et al. 1995; Jolliffe 2002). Data were log-transformed, with the exception of the silt-clay fraction and TOM, which were transformed as $y=\arcsin \sqrt{p}$ where $p=x_{i} / 100$, to meet assumptions of normality and homoscedasticity. We used one-way MANOVA and Tukey's test to evaluate environmental and biotic variables separately (Zar 1999).

Adult and juvenile $(21-90 \mathrm{~mm}$, mean $=49.49 \pm$ $15.96 \mathrm{~mm}$ ) specimens of $A$. affinis chiliensis were separated from other macrofauna under a stereoscopic microscope. All specimens were counted and weighed (wet weight) to the nearest $0.001 \mathrm{~g}$. Following these measurements the specimens were transferred to $70 \%$ ethanol for conservation. Voucher samples from this study were deposited in the Colección Flora y Fauna Profesor Patricio Sánchez Reyes of the Departamento de Ecología, Pontificia Universidad Católica de Chile, in Santiago, under the registration code SSUC 7004.

\section{Results}

\section{Environmental variables}

The sediment in the CGR study area was principally composed of sand, ranging from fine sand to silt-clay. Average grain size ranged from 2.74 to $3.47(\phi)$ during both sampling periods (Table 1). Classification analysis of sediments from CGR indicated that the coefficient of selection (ds) ranged from moderate to poorly sorted sediments, with values of 0.60 and $1.31(\phi)$ during both sampling periods (Table 1). The siltclay fraction ranged from 1.56 to $35.3 \%$ (mean \pm $\mathrm{SD}=18.81 \pm 12.19)$ during 1996 , and from 1.27 to $24.20 \%(14.21 \pm 8.40)$ in 1997 (Table 1). In 1996 the average amount of TOM for the area was $23 \%$, where stations 1, 2, 3 and 7 presented the highest amount of organic matter, ranging between 27 and $32 \%$. A similar tendency was recorded in 1997, with an average TOM of $20 \%$ (Table 1 ).

In 1996 salinity values fluctuated between 34.82 and 34.96 psu, with an average value of 34.92 psu for the study area. In 1997, we recorded an increase in salinity, with values ranging from 35.20 to 35.48 psu, with an average of 35.37 psu (Table 1). In 1996, DO values were between 0.75 and $1.23 \mathrm{ml} \mathrm{O} / 1$, with an average value of $1.0 \mathrm{ml} \mathrm{O}_{2} / \mathrm{l}$. In $1997 \mathrm{DO}$ values were between 0.82 and $1.41 \mathrm{ml} \mathrm{O}_{2} / 1$, with an average of $1.17 \mathrm{ml} \mathrm{O}_{2} / 1$ (Table 1). The average value of DO for both years combined was $1.08 \mathrm{ml} \mathrm{O}_{2} / 1$.

A MANOVA using the environmental variables showed significant differences between years (MANOVA, Wilk's $\lambda=0.048 ; F_{(6,7)}=23.00 ; P<0.001$ ), due only to significant differences in salinity (Tukey's 
Table 1 Environmental parameters and sediment granulometric attributes for the seven sampling stations of the CGR sampling area in northern Chile during September 1996, and September 1997
GMS average particle size $(\phi), d s$ coefficient of "sorting" $(\phi), S C$ silt-clay fraction (\%), TOM total organic matter (\%), $D O$ dissolved oxygen $\left(\mathrm{ml} \mathrm{O}_{2} / \mathrm{l}\right)$ and $S$ salinity (psu)

\begin{tabular}{lllrrrr}
\hline Station & GMS & ds & SC & TOM & DO & S \\
\hline \multicolumn{2}{l}{ September 1996 } & & & & & \\
1 & 2.94 & 1.18 & 23.54 & 31.62 & 1.14 & 34.96 \\
2 & 2.94 & 1.31 & 27.27 & 32.10 & 1.23 & 34.82 \\
3 & 3.32 & 0.95 & 35.30 & 28.52 & 1.04 & 34.95 \\
4 & 3.06 & 0.76 & 3.88 & 13.91 & 0.75 & 34.93 \\
5 & 2.94 & 1.12 & 20.89 & 25.48 & 0.86 & 34.94 \\
6 & 3.05 & 0.63 & 1.56 & 4.18 & 0.82 & 34.96 \\
7 & 2.83 & 1.03 & 19.24 & 27.80 & 1.14 & 34.86 \\
Mean & 3.02 & 1.00 & 18.81 & 23.37 & 1.00 & 34.92 \\
SD & 0.16 & 0.24 & 12.18 & 10.43 & 0.19 & 0.06 \\
September 1997 & & & & & \\
1 & 3.32 & 0.98 & 20.23 & 19.25 & 1.15 & 35.20 \\
2 & 2.73 & 1.14 & 8.88 & 28.40 & 1.09 & 35.45 \\
3 & 3.06 & 0.90 & 11.25 & 19.56 & 1.41 & 35.48 \\
4 & 2.94 & 1.06 & 12.33 & 22.52 & 0.82 & 35.47 \\
5 & 3.47 & 0.93 & 24.20 & 22.47 & 1.50 & 35.28 \\
6 & 3.18 & 0.60 & 1.27 & 2.89 & 0.99 & 35.47 \\
7 & 3.18 & 1.12 & 21.33 & 25.85 & 1.21 & 35.22 \\
Mean & 3.13 & 0.96 & 14.21 & 20.13 & 1.17 & 35.37 \\
SD & 0.24 & 0.18 & 8.11 & 8.27 & 0.23 & 0.13 \\
\hline
\end{tabular}

test, $d f=12 ; P<0.001)$. The spatial distribution of the environmental variables is shown in Fig. 3.

\section{Abundance and biomass}

For both sampling years the numerical contribution of A. affinis chiliensis to total benthic macrofauna was greater than $80 \%$. In 1996, the pooled density of $A$. affinis chiliensis for the seven sampling stations was 122 -ind $/ 1.4 \mathrm{~m}^{2}$, while in 1997 density was 187-ind/ $1.4 \mathrm{~m}^{2}$. For both sampling periods the highest abundances were recorded for stations 3 and 6 (Fig. 4a). A similar tendency was observed in biomass, with $A$. affinis chiliensis contributing to more than $95 \%$ of total biomass (Table 2). Specifically, the pooled biomass of

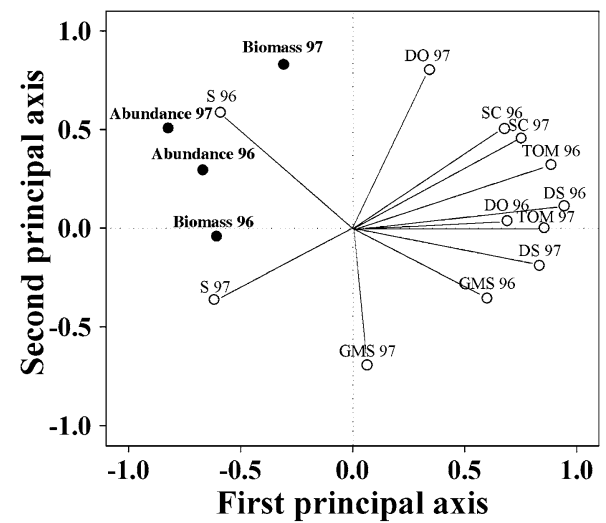

Fig. 3 Spatial distribution from the principal components analysis (PCA) of the environmental and biotic variables measured in CGR during September 1996 and 1997, using station as the variable (for abbreviations see Table 1)
A. affinis chiliensis in 1996 was $46.80 \mathrm{~g} / 1.4 \mathrm{~m}^{2}$, while in 1997 it was $51.38 \mathrm{~g} / 1.4 \mathrm{~m}^{2}$. The highest biomass in 1996 corresponded to stations 3 and 7; while in 1997 the highest values were found at stations 3 and 5 (Fig. 4b).

A multivariate analysis of the biological variables did not show significant differences between years (MANOVA, Wilk's $\left.\lambda=0.883 ; \mathrm{F}_{(2,11)}=0.727 ; P=0.504\right)$.
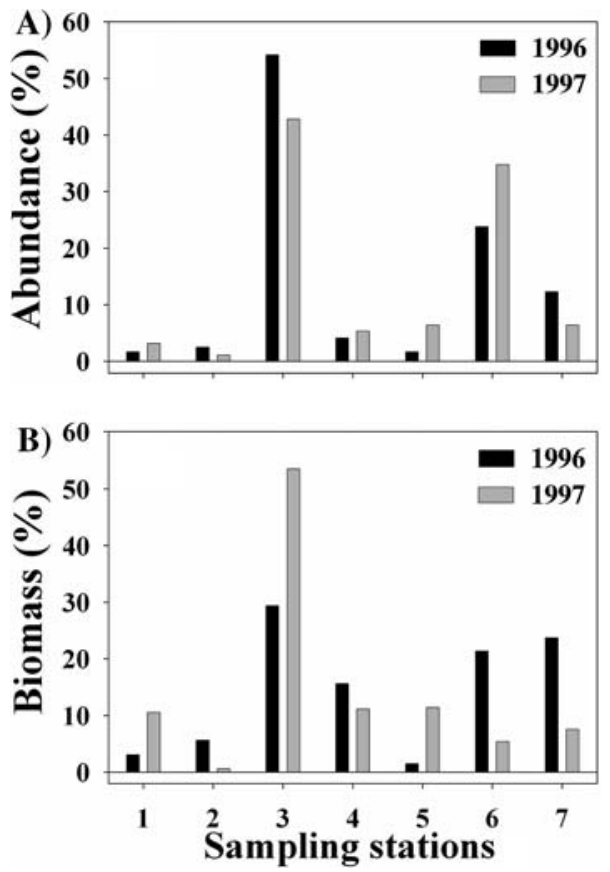

Fig. 4 a Numerical abundance and b biomass of Abarenicola affinis chiliensis collected in $0.2 \mathrm{~m}^{2}$ sediment samples from the seven benthic sampling stations in CGR, during September 1996 and 1997 
The spatial distribution of abundance and biomass is shown in Fig. 3, which indicates that both abundance and biomass are spatially distributed near to the salinity variable.

\section{Discussion}

Our study presents the first information on a species of the genus Abarenicola in the southeastern Pacific. The ecological importance of lugworms as significant components of abundance and biomass in benthic animal communities of shallow soft bottoms has been recognized worldwide (see Wells 1963b; Jacobsen 1967; Flach and Beukema 1994), and conforms to our observation that $A$. affinis chiliensis is a dominant species in terms of abundance and biomass in the shallow subtidal sediments of CGR (Table 2).

Our results on environmental variables agree with the study by Hobson (1967) on Abarenicola pacifica Healy and Wells in False Bay, Washington. This species is distributed in poorly sorted muddy sediments with high organic matter content, in zones with low wave and current action. Nevertheless, our data do not concur with reports on $A$. vagabunda Healy and Wells (A. claparedi vagabunda) (see Hylleberg 1975), which is sympatric with $A$. pacifica in False Bay (Healy and Wells 1959; Hobson 1967), inhabiting clean sands with low organic content and increased wave action and currents. According to Hobson (1967), the pattern shown for $A$. vagabunda is the result of physical and biological factors (i.e., predation, larval ecology), which govern its distribution.

Values of TOM from the study area indicate organic enrichment of the upper sediment layer, which has also been reported for other bays in the southeastern Pacific. In central Chile the maximum values of TOM reported for organically enriched environments fluctuate between $13 \%$ for the port of Talcahuano (Oyarzún et al. 1987) and approximately 20\% for San Vicente Bay (Carrasco and Carbajal 1998). Compared with these organically enriched areas, the CGR study

Table 2 Contribution of $A$. affinis chiliensis to the total abundance and biomass of the benthic macrofauna $(>0.5 \mathrm{~mm})$ found in pooled replicates $\left(1.4 \mathrm{~m}^{2}\right)$ from sediments of the seven benthic sampling stations in the CGR sampling area off northern Chile

\begin{tabular}{lllll}
\hline & \multicolumn{2}{l}{ Abundance (N) } & \multicolumn{2}{l}{ Biomass (g) } \\
\hline Cruise & 1996 & 1997 & 1996 & 1997 \\
Total macrofauna & 149 & 233 & 46.89 & 53.12 \\
A. affinis chiliensis & 122 & 187 & 46.80 & 51.29 \\
A. affinis chiliensis (\%) & 81.88 & 80.26 & 99.81 & 95.55 \\
\hline
\end{tabular}

area can be categorized as a zone greatly enriched with organic matter of anthropogenic origin. Our results show that $A$. affinis chiliensis inhabits sediments with an average organic content of $20 \%$ (Table 1). This situation is quite different from that recorded for other congeneric species in the northern Pacific, which inhabit sediments with less organic content (see Hobson 1967; Hylleberg 1975).

Average values of DO and salinity in the study area indicate that $A$. affinis chiliensis inhabits waters deficient in dissolved $\mathrm{O}_{2}(<1.5 \mathrm{ml} / \mathrm{l})$, associated with the equatorial subsurface waters (ESSW) (34.4-34.9 psu) (Silva and Konow 1975; Silva and Neshyba 1979). This polychaete species appears to be adapted to these environmental conditions given its closed circulatory system and high average concentrations of extracellular hemoglobin dissolved in the blood $(7.2 \mathrm{~g} / \mathrm{dl})$, which could play an important role in the survival of this species under hypoxic conditions (Leoncini 2003). These results are in agreement with the generally established pattern of Arenicolidae inhabiting intertidal and shallow subtidal zones, which are adapted to living in poorly oxygenated muddy sediments (Hutchings 2000). The hypoxic conditions registered in CGR are temporally stable, as a result of the geographic position of the area, which is located within an area of the Pacific Ocean with low DO content (see Arntz et al. 1991; Díaz and Rosenberg 1995; Levin 2003; Helly and Levin 2004). This stability is further reinforced by the circulation characteristics and bathymetry of the semi-enclosed CGR study area.

Statistical analyses did not detect significant differences between years for the measured environmental and biotic variables (with the exception of salinity, which showed a slight increase), indicating that environmental conditions in CGR during the study period were temporally stable, allowing the $A$. affinis chiliensis population to persist in time (in terms of abundance and biomass) on the shallow soft bottoms of this area of northern Chile.

According to Wells (1963b, 1964), the worldwide distribution of lugworms is directly or indirectly governed by sea surface temperatures. In this sense the isotherms of 10 and $20^{\circ} \mathrm{C}$ could act as physical barriers to dispersal, favoring speciation. The species of Abarenicola are found to be restricted by the $10^{\circ} \mathrm{C}$ isotherm in the cold water zone of southern South America. The only exception is A. pusilla, which behaves like an "aberrant" species, being distributed in warm temperate coastal waters. Nevertheless, our study on A. affinis chiliensis does not support the hypothesis of Wells since it showed that this species is also distributed in warm temperate waters, where the 
isotherm fluctuates between 18 and $24^{\circ} \mathrm{C}$ depending on season and wind prevalence (Castilla et al. 1993; Fernández et al. 2000). Reference data of average water temperature at the bottom in the CGR study area for spring and summer periods $\left(>16.5^{\circ} \mathrm{C}\right)$ also support our observations (Moreno and Marinkovic, unpublished data). Therefore, we propose that an $A$. affinis chiliensis population was able to disperse from the cold temperate waters of southern Chile (ca. $42^{\circ} \mathrm{S}$ ) towards low latitudes $\left(20^{\circ} 10^{\prime} \mathrm{S}\right)$, where it was able to establish pioneer populations in the shallow subtidal zone of the CGR, located in the extreme northern region of Chile. Nevertheless, to support this hypothesis it is necessary to obtain information on the ranges of physiological tolerance of this species. In this sense, Tarazona et al. $(1988,1996)$ reported the presence of one species of Arenicolidae in benthic samples from the warm temperate waters of Ancón Bay and Independencia Bay in Perú. Although this species has not yet been identified to the specific level, if it belongs to Abarenicola this would provide further support for the idea that the $10^{\circ} \mathrm{C}$ isotherm is not a barrier to the dispersal of this genus. The findings from our study suggest that the hypothesis of Wells (1963b, 1964) should be reexamined for some representatives of Abarenicola on the southeastern Pacific coast.

Acknowledgments The authors are very grateful to José Miguel Fariña, Paula E. Neill, Roberto Nespolo and Marcelo M. Rivadeneira for comments and suggestions that greatly improved the manuscript. We thank Guillermo Guzmán and Raúl Soto from Universidad Arturo Prat for help in collecting and sorting samples. We acknowledge the cooperation of Andrés Charrier for the photograph of Abarenicola affinis chiliensis and Carlos Garín for the map. We are grateful to Prof. Dr. Heinz-Dieter Franke and one anonymous reviewer for their valuable recommendations, which improved this manuscript. Rodrigo A. Moreno, Wolf E. Arntz and Sven Thatje were supported by the EU-project CENSOR "Climate variability and El Niño Southern Oscillation: Impacts for natural resources and management", contract 511071 to the Alfred Wegener Institute for Polar and Marine Research (AWI), Bremerhaven, Germany and National Oceanography Centre (NOC), University of Southampton, United Kingdom. This is CENSOR publication 0033. Roger D. Sepúlveda was supported by a CONICYT-Chile Doctoral Fellowship. This publication was completed during a research stay in Germany financed by AWI to the first author.

\section{References}

Alvial H, Moraga J (1986) Estudio de la circulación de la Bahía de Iquique $\left(20^{\circ} 12^{\prime} \mathrm{S} ; 70^{\circ} 10^{\prime} \mathrm{W}\right)$ usando derivadores. Invest Mar 14:17-33

Arntz WE, Tarazona J, Gallardo VA, Flores L, Salzwedel H (1991) Benthos communities in oxygen deficient shelf and upper slope areas of the Peruvian and Chilean Pacific coast, and changes caused by El Niño. In: Tyson RV,
Pearson TH (eds) Modern and ancient Continental Shelf Anoxia. Geological society special publication, London, pp 131-154

Buchanan J (1971) Measurements of the physical and chemical environment. In: Holme N, McIntyre A (eds) Methods for the study of marine benthos. Blackwell, Oxford, pp 30-58

Carrasco FD, Carbajal W (1998) The distribution of polychaete feeding guilds in organic enriched sediments of San Vicente Bay, Central Chile. Internat Rev Ges Hydrobiol 83:233-249

Castilla JC, Navarrete SA, Lubchenco J (1993) Southeastern Pacific coastal environments: main futures, large-scale perturbations, and global climate change. In: Mooney HA, Fuentes ER, Kronberg BI (eds) Earth system responses to global change. Contrast between North and South America. Academic, New York, pp 167-188

Díaz R, Rosenberg R (1995) Marine benthic hypoxia: a review of its ecological effects and the behavioural responses of benthic macrofauna. Ocean Mar Biol Ann Rev 33:245-303

Fauchald K, Rouse G (1997) Polychaete systematics. Past and present. Zool Scr 26:71-138

Fernández M, Jaramillo E, Marquet PA, Moreno CA, Navarrete SA, Ojeda FP, Valdovinos C, Vásquez J (2000) Diversity, dynamics and biogeography of Chilean benthic nearshore ecosystems: an overview and guidelines for conservation. Rev Chil Hist Nat 73:797-830

Flach EC, Beukema JJ (1994) Density-governing mechanism in populations of the lugworm Arenicola marina on tidal flats. Mar Ecol Prog Ser 115:139-149

Folk R (1974) Petrology of sedimentary rocks. Hemphill Publishing, Austin

Healy EA, Wells GP (1959) Three new lugworms (Arenicolidae, Polychaeta) from the North Pacific area. Proc Zool Soc Lond 133:315-335

Helly JJ, Levin LA (2004) Global distribution of naturally occurring marine hypoxia on continental margins. Deep-Sea Res 51:1159-1168

Hernández CE, Moreno RA, Rozbaczylo N (2005) Biogeographical patterns and Rapoport's rule in southeastern benthic polychaetes of the Chilean coast. Ecography 28:363373

Hobson KD (1967) The feeding and ecology of two North Pacific Abarenicola species (Arenicolidae, Polychaeta). Biol Bull 133:315-335

Hutchings P (2000) Family Arenicolidae. In: Beesley PL, Ross GJB, Glasby CJ (eds) Polychaetes and Allies: the Southern synthesis. Fauna of Australia. vol 4A. Polychaeta, Myzostomida, Pogonophora, Echiura, Sipuncula. CSIRO Publishing, Melbourne, pp 62-67

Hylleberg J (1975) Selective feeding by Abarenicola pacifica with notes on Abarenicola vagabunda and a concept of gardening in lugworms. Ophelia 14:113-137

Jacobsen VH (1967) The feeding of the lugworm, Arenicola marina (L.). Quantitative studies. Ophelia 4:91-109

Jolliffe IT (2002) Principal component analysis. Springer, Berlin Heidelberg New York

Jongman RHG, ter Braak CJF, van Tongeren OFR (1995) Data analysis in community and landscape ecology. Cambridge University Press, Cambridge

Leoncini R (2003) Determinación de la concentración de hemoglobina in vivo en Abarenicola cf. pusilla (Quatrefages 1865) (Polychaeta: Arenicolidae) extraídos en Caleta Guardiamarina Riquelme $\left(20^{\circ} 12^{\prime} 20^{\prime \prime} \mathrm{S}, 70^{\circ} 09^{\prime} 10^{\prime \prime} \mathrm{W}\right)$, Chile. Marine Biology thesis, Universidad Arturo Prat, Chile

Levin LA (2003) Oxygen minimum zone benthos: adaptation and community response to hypoxia. Ocean Mar Biol Ann Rev 41:1-45 
Levin LA, Blair N, De Master D, Plaia G, Fornes W, Martin C, Thomas C (1997) Rapid subduction of organic matter by maldanid polychaetes on the North Carolina slope. J Mar Res 55:595-611

Marinkovic M (2000) Efecto de la contaminación en Caleta Guardiamarina Riquelme $\left(20^{\circ} 12^{\prime} 20^{\prime \prime} \mathrm{S}, 70^{\circ} 09^{\prime} 10^{\prime \prime} \mathrm{W}\right)$, Chile: evaluación del macrobentos y de las condiciones físico químicas del sedimento y agua suprayacente. Marine Biology thesis, Universidad Arturo Prat, Chile

McLusky DS, Anderson FE, Wolfe-Murphy S (1983) Distribution and population recovery of Arenicola marina and other benthic fauna after bait digging. Mar Ecol Prog Ser 11:173179

Moreno RA, Hernández CE, Rivadeneira MM, Vidal MA, Rozbaczylo N (2006) Patterns of endemism in south-eastern Pacific benthic polychaetes of the Chilean coast. J Biogeogr 33:750-759

Oyarzún C, Carrasco FD, Gallardo VA (1987) Some characteristics of macrobenthic fauna from the organic-enriched sediments at Talcahuano, Chile. Cah Biol Mar 28:429-446

Rouse G, Pleijel F (2001) Polychaetes. Oxford University Press, Oxford

Silva N, Konow D (1975) Contribución al conocimiento de las masas de agua en el Pacífico sudoriental. Expedición Krill. Crucero 3-4, julio-agosto 1974. Rev Com Perm Pac Sur 3:63-75

Silva N, Neshyba S (1979) On the southernmost extension of the Perú-Chile undercurrent. Deep-Sea Res 26:1387-1393

Strickland JDH, Parsons T (1972) A Practical handbook of sea water analysis. Bull Fish Res Bd Can 167:1-311
Swinbanks DD (1981) Sediment reworking and the biogenic formation of clay laminae by Abarenicola pacifica. J Sed Res 51:1137-1145

Tarazona J, Salzwedel H, Arntz WE (1988) Oscillations of macrobenthos in shallow waters of the Peruvian central coast induced by El Niño 1982-83. J Mar Res 46:593-611

Tarazona J, Arntz WE, Canahuire E (1996) Impact of two "El Niño" events of different intensity on the hypoxic soft bottom macrobenthos off the central Peruvian coast. Mar Ecol 17:425-446

Wells GP (1954) A preliminary account of the Arenicolidae (Polychaeta). Lunds Univ Årsskr Adv 2 50:1-6

Wells GP (1959) The genera of Arenicolidae (Polychaeta). Proc Zool Soc Lond 133: 301-314

Wells GP (1963a) The lugworms of the southern cold temperate zone (Arenicolidae, Polychaeta). Proc Zool Soc Lond 140:121-159

Wells GP (1963b) Barriers and speciation in lugworms (Arenicolidae, Polychaeta). In: Harding JP, Tebble N (eds) Speciation in the sea. The Systematics Association, London, pp 79-98

Wells GP (1964) Temperature, taxonomic technique and the zoogeography of lugworms (Arenicolidae, Polychaeta). Helgolander Wiss Meeresunters 10:404-410

Zal F, Lallier F, Toulmond A (2002) Utilisation comme substitute sanguine d'une hémoglobine extracellulaire de poids moléculaire élevé. French Patent $\mathrm{N}^{\circ} 0007031$ granted 2 August

Zar JH (1999) Biostatistical analysis. Prentice-Hall, NJ 